\title{
TEAD4 wt Allele
}

National Cancer Institute

\section{Source}

National Cancer Institute. TEAD4 wt Allele. NCI Thesaurus. Code C158839.

Human TEAD4 wild-type allele is located in the vicinity of 12p13.33 and is approximately $81 \mathrm{~kb}$ in length. This allele, which encodes transcriptional enhancer factor TEF-3 protein, is involved in both the regulation of organ size and tumor suppression. 